\title{
A Stylistic Analysis of Shakespeare's Sonnet 130
}

\author{
Dr. Wisam Khalid Al Shawa \\ Al Quds Open University Palestine
}

\begin{abstract}
Stylistics as a science tries to analyze the choice of words, the pattern of the sentence and the figurative language that a poet uses in his poetical works in order to reinforce and emphasize the ideas and sentiments he wants to convey to the readers. This paper aims to analyze Shakespeare's sonnet 130 "My Mistress' Eyes Are Nothing Like The Sun" from the perspective of stylistic analysis. The analysis is made under the aspects of Graphlogical, Grammatical, Syntactical, and Phonological patterns. Troops and schemes are also described that are present in the poem. This analysis is helpful in understanding the basic concept of sonnet, the structure and style of Shakespeare's poetry, and his themes, views, and treatment of love. Though this poem is personal in tone and mood but its ideas are somewhat strange. The poem is simple but the theme is universal. Shakespeare conveyed his theme by using different stylistic devices.
\end{abstract}

Keywords: Stylistics, Shakespeare, lyric, graphological level, phonological level, morphological level.

\section{INTRODUCTION}

Style is popularly referred to as 'dress' of thought. It describes the way of person's speaking, writing and his emotions or thoughts. Leech and Short (1981) is of the view that the word - style has an uncontroversial meaning. It is a way in which language is being used in a given context for a given purpose. Haynes (1989) believes that the study of style is the study of distinctions: looking at what was said against what might have been said. Style is almost synonymous with variety. Style refers in a simple way to the manner of expression which differs according to the various contexts. Lawal (1997) described style as an aspect of language that deals with choices of diction, phrases, sentences and linguistic materials that are consistent and harmonious with the subject matter.

The term "style" is widely used in literature to signify literary genre. Thus, we speak of classical style, realistic style, the style of romanticism. A poet's style is of great significance in order to understand the meaning of any given text by him/her because it deals with content and form. Style in poetry is the literary element that describes the ways that the poet uses words to convey meaning, emotions, tone in his poem. Style describes how the author describes events, objects, and ideas. Also words are usually chosen for sound as well as for meaning. The arrangement of these words in a verse line, as well as the arrangement of lines in the whole poem both contribute heavily to a poet's style. Learning about a poet's style is referred to as stylistic.

Stylistics is a science that provides us with the necessary background to understand and appreciate the literary work. Widdowson (1975) mentions that the study of literary text which shows linguistic orientation is stylistics. He defines stylistics as the study of literary discourse from a linguistic orientation. Carter (1989) believes that style is generally depends on linguistic levels. Due to these levels every text and writing is different from the other, hence every genre is different. According Turner (1975) stylistics is described as a field of linguistics which puts emphasis on the changes in complex uses of language. Bradford (1997) thinks that stylistics is a fallacious topic. Bradford (1997) says that stylistics is "an elusive and slippery topic every contribution to the vast multifaceted discipline of literary studies will involve an engagement with style". Verdonk(2002) defines stylistics as "the analysis of distinctive expression in language and the description of its purpose and effect".

The poem to be analyzed in this paper is one of the most memorized sonnets ever written by William Shakespeare "My Mistress Eyes are nothing Like the Sun". The aim behind choosing this great sonnet for the data analysis is its usefulness in order to understand Shakespearean sonnets and because it is different somehow from the other sonnets in its ideas. The following is sonnet 130 that is the focus of the stylistic analysis:

My mistress' eyes are nothing like the sun;

Coral is far more red than her lips' red;

If snow be white, why then her breasts are dun;

If hairs be wires, black wires grow on her head.

I have seen roses damask'd, red and white,

But no such roses see I in her cheeks; 
And in some perfumes is there more delight

Than in the breath that from my mistress reeks.

I love to hear her speak, yet well I know

That music hath a far more pleasing sound;

I grant I never saw a goddess go;

My mistress, when she walks, treads on the ground:

And yet, by heaven, I think my love as rare

\section{Research problem:}

It is noted that many researchers tries to study several poems written by Shakespeare but the stylistic analysis of Shakespeare's "My Mistress' eyes are Nothing Like the Sun" has not been done before. So this paper will address itself to analyzing this sonnet stylistically and examining the uniqueness of stylistics as it combines both linguistics and literary studies within a literary work. It also addresses itself to examining how words are put together in transforming the poet's message to the reader.

\section{Research Questions}

1.How to explore the poem at graphological level?

2 . How to explore the poem at grammatical level?

3.How to analyze the poem at morphological level?

4.How to assess the poem at phonological level?

5. How to evaluate the language devices that has been integrated in the poem?

\section{Objectives}

1.To investigate the poem at graphological level.

2. To investigate the poem at grammatical level

3.To investigate the poem at morphological level.

4.To examine the poem at phonological level.

5. To evaluate how language devises has been integrated in the poem.

\section{Scope of the study}

This study shall be stylistic and the analysis will be conducted through the use of the following levels of analysis: graphological, morphological, phonological and lexico-syntactic levels.

\section{Justification}

Shakespeare's sonnet 130 is a distinguished and beautiful poem and it addresses a universal theme that can be applicable to any time, it is rich in meaning and exuberant. Shakespeare's style and choice of words have made the researcher to embark on this study. This paper will be of great benefit to the learners of English language and literature and those who are interested in the field of stylistics.

\section{Level of Stylistic Analysis}

The following are five levels of stylistics that we use them in order to analyze the literary text:

1. Phonetic Level: It is an analysis of sounds; we study the features and possible function of sounds in phonetic level.

2. Phonological Level: It is the study of the sound patterns of a given language; the formal rules of pronunciation, the rhyming scheme and utterance of the word in the sentence.

3. Graphlogical Level: It is the analogous study of a language's writing system. It deals with the systematic formation, structure and punctuation in the sentence.

4. Grammatical Level: in this level both the syntactic and morphological levels are discussed. The main aim of this level is to study and analyze the words, internal structure of sentences and their formation.

5. The Lexico-syntax level: It is the study of the way in which individual words and idioms tend to pattern in different linguistic context; on the semantics level in terms of stylistics.

\section{The poet and the Poem}

\section{William Shakespeare: The Poet}

William Shakespeare (1564-1616) is one of the most brilliant and famous distinguished English playwright, actor and poet. He produced most of his best work between 1589 and 1613 . He contributed heavily to the humanity and to the development of theatre in the late $16^{\text {th }}$ century. Shakespeare is universally considered to be the greatest writer and dramatist in the English literature. He wrote154 sonnets and 38 plays. Shakespeare's plays remain highly popular today and are constantly studied, performed, and reinterpreted in 
diverse cultural and political contexts throughout the world. The plays contain songs of various types thus illustrating Shakespeare's genius in musicality and humor. In his poems he talked about the themes of love, beauty, death, decay and the inevitable passing of time.

\section{Distinguished Features of Shakespeare's Poetry}

Shakespeare wrote his earlier plays in the traditional style of the time. He relied heavily on using lengthy and sometimes exaggerated metaphors and narcissisms. His style often sounded imperious and pretentious. His sonnets are written in simple way simply because most of them are about love.

\section{Introduction to the poem}

My Mistress' Eyes are Nothing Like the Sun by William Shakespeare is seen as an anti-metaphorical sonnet, unlike the other famous sonnets of the Elizabethan Age. It stands apart from most of his sonnets for its mocking voice, use of satire and even its strange ideas. In this sonnet William Shakespeare forms an argument against conventions to flatter one's lover with praise of her beauty as well as make comments about the way that love between two people can be expressed and interpreted. He uses the example of a woman who is not physically perfect or even beautiful in order to emphasize and stress the idea that love is deeper and more important than these superficial and trivial comparisons about body beauty. While his mistress may not have had silky and beautiful hair and sweet breath, he is still totally captivated by her and considers his love to be as rare as any other.

This sonnet compares the speaker's lover to a number of other beauties but what we can see is that no comparison is in the lover's favor. Her eyes are "nothing like the sun," her lips are less red than coral; compared to white snow, her breasts are dun-colored, and her hairs are like black wires on her head. In the second quatrain, the speaker says he has seen roses separated by color ("damasked") into red and white, but he sees no such roses in his mistress's cheeks; and he says the breath that "reeks" from his mistress is less delightful than perfume. In the third quatrain, he admits that, though he loves her voice, music "hath a far more pleasing sound," and that, though he has never seen a goddess, his mistress--unlike goddesses--walks on the ground. In the couplet, however, the speaker declares that, "by heav'n," he thinks his love as rare and valuable "As any she belied with false compare"--that is, any love in which false comparisons were invoked to describe the loved one's beauty.

\section{Title of the poem}

Shakespearean sonnets have no titles, they only carry numbers. In sonnet 130 , the first line tells us that the whole sonnet is about the poet's beloved mistress who is not physically beautiful but he loves here a lot because his love is honest and deep. He described her features and compares her to the beauty of nature but we discover that she is an ugly lady but this ugliness is not important for the poet because her soul is so beautiful and he loves her deeply. The theme of honesty is present in the poem which could demonstrate how genuine his love is.

\section{The poem as a sonnet}

A Sonnet is a poem of an expressive idea consists of 14 lines. It is written in iambic pentameter, a poetic meter with 10 beats per line made of alternating unstressed and stressed syllables, and a strict rhyme scheme. It gives an ideal laboratory to a poet for exploration of strong emotions. Due to its short length, it is easy to manage for both the writer and the reader. The sonnets can be categorized into three major types:

- Italian Sonnet was introduced by an Italian poet Petrarch. Its rhyme scheme has first eight lines called octave that rhymes as $a b b a-a b b a-c d c-d c d$. The remaining six lines called sestet might have a range of rhyme schemes.

- Shakespearean sonnet is generally written in an iambic pentameter. Its rhyme scheme is a b a b - c d c de $f$ e $f-g$ g. It contains three quatrains and a couplet.

- Spenserian Sonnet was created by Sir Edmund Spenser who modified the Petrarch's form and introduced a new rhyme scheme which is $a b a b-b c b c-c d c d-e$.

\section{Themes of the poem}

Sonnet 130 makes fun of exaggerative language to give a more realistic description of a woman. There are several universal themes that Shakespeare presented in this sonnet as:

1- Love: In this sonnet Shakespeare gave us an accurate description of his mistress; he gave us an idea about what his love is like.

2- Appearances: Shakespeare described what is wrong with his beloved lady's looks. He poked fun at our obsession with looks and appearances 
3- The nature of female beauty. This sonnet is about female beauty and how we expect women to look. The poet here points out that love poetry does the same thing. It makes women goddess, not real human beings. He insists that the idea of beautiful females does not depend on fitting an abstract, unrealistic fantasy. The poet also mocks the empty praise and insincerity of clichéd poems

\section{Frame Work}

This work is a stylistic analysis of sonnet 130. The poem is analyzed on different levels of stylistics. Qualitative and descriptive method is used in this work. The data for analysis is the sonnet of Shakespeare. Shakespeare wrote 154 sonnets. But the sonnet which is selected for analysis in this research study is sonnet 130 .

\section{Stylistic Analysis of Sonnet 130:}

We can analyze this sonnet on various levels as follows:

\section{Graphological level:}

1. There are 14 lines in this sonnet.

2. First 12 lines are divided into 3 quatrains with 4 lines each and then last 2 lines couplet.

3. There are 123 words in this sonnet.

4. There is usual capitalization at the beginning of each poetic line.

5. There is no use of underline, italic or bold letters.

6. There is use of Apocope for once e.g. damask'd.

4. Punctuation marks are used in the poem. For example: full stop, comma, colon, semicolon and apostrophe are used in this poem. Punctuation marks such as Commas, semi colon, and colon are used to make the poem easily comprehendible.

The use of punctuation is also something of note.

\section{Grammatical level:}

Full stop:

The poet used the full stop 3 times. He used it at the end of each quatrains and the couplet to show the effect of separating thoughts that are meant to be digested one at a time.

If hairs be wires, black wires grow on her head. (4)

Than in the breath that from my mistress reeks. (8)

As any she belied with false compare. (14)

\section{Colon:}

Willaim Shakespeare used the colon just one time prior to the heroic couplet shows it's complete relation to the rest of the poem, and it's indentation highlights its importance.

My mistress, when she walks, treads on the ground: (12)

\section{Comma (caesura)}

William Shakespeare used a comma in the middle of the following lines which is called in poetry as a caesura. Caesura is used a lot because Shakespeare's Sonnet 130 begins with a quatrain that is filled with antithesis and makes good use of caesuras.

If snow be white, why then her breasts are dun; (3)

If hairs be wires, black wires grow on her head. (4)

I have seen roses damask'd, red and white, (5)

I love to hear her speak, yet well I know (9)

My mistress, when she walks, treads on the ground: (12)

And yet, by heaven, I think my love as rare (13)

He used it in order to cause a break in the poem, increasing the sense of expectation and prediction.

\section{Semicolon:}

The semi-colon is one of those weird bits of punctuation whose purpose is a bit obscure. Sometimes the poets used semi-colon as a cautionary pause. In fact it signifies a distinct separation with the following thoughts or lines. In Shakespeare's poem semicolons are used to connect two independent clauses which are related somehow. They work like a soft period, separating the thoughts but keeping the flow of the first sentence. The poet used the semi-colon six times in the poem. The use of semicolons at the end of the lines instead of full stops adds to the flow. Here are the examples: 
My mistress' eyes are nothing like the sun; (1)

Coral is far more red than her lips' red; (2)

If snow be white, why then her breasts are dun; (3)

But no such roses see I in her cheeks; (6)

That music hath a far more pleasing sound; (10)

I grant I never saw a goddess go; (11)

\section{Anastrophe:}

Anastrophe is the inversion of natural order of sentence structure. Shakespeare used it twice in the sonnet:

But no such roses see I in her cheeks; (6)

And in some perfumes is there more delight line (7)

\section{Paragraphing}

\section{Syntactic parallelism}

In the following two successive lines, the poet began the sentences with the conjunction If so both sentences have a conditional clause broken by a caesura.

If snow be white, why then her breasts are dun; (3)

If hairs be wires, black wires grow on her head. (4)

\section{Sonnet sentences:}

The sonnet's sentences are all declarative sentence types. The first 4 lines make up one complex sentence:

My mistress' eyes are nothing like the sun;

Coral is far more red than her lips' red;

If snow be white, why then her breasts are dun;

If hairs be wires, black wires grow on her head.

After this comparisons expand across 2 sentences so the speaker can expand his argument and change the flow of the sonnet so it's not stagnant.

Some sentences exhibit an interrogative tone as in lines 3 and 4:

If snow be white, why then her breasts are dun;

If hairs be wires, black wires grow on her head.

This tone gives a controversial narrative.

The sentences follow typical SVO order but there is an inversion in line 6 that contains verb subject inversion because in early modern English if the initial clause contained negation the verb could come before the subject:

But no such roses see I in her cheeks;

Shakespeare's sonnets don't have stanzas, but the groups of four lines, or quatrains, contribute a similar sense of development that different stanzas might.

- The first quatrain describes the mistress' appearance in frank and honest terms.

- The second is more fanciful and moves away from the woman to use another point of comparison - roses, the sight of which links to the idea of perfume (smell) enabling Shakespeare to deliver the killer line on reeking breath. These two quatrains form the octave which is primarily concerned with what the woman is not like.

- The third quatrain focuses on the sound and motion of his mistress and, with the final couplet, forms the last six lines, known as the sestet of the sonnet. Here the poem shifts away from the negative comparison of the octave to more objective description; he 'loves to hear her speak' and she 'walks...on the ground'.

The final couplet gives an example of a volta. This often comes in line nine of a sonnet. Here the sudden move towards praise is very near the end. This contributes to the impact of the sincerity of what the poet expresses in the couplet, making the reader reconsider the 'criticisms' of earlier in the poem. The volta forces us to ask whether it was the woman or other poets who were in the firing line. If we thought the poet was harsh on his lover, we can see with greater clarity Shakespeare's mockery of other poets.

\section{Phonological level:}

This level deals with the study of sound system. It also discusses the rules of pronunciation, meter, rhyme scheme and utterance of the words in the sentence. Phonological devices include alliteration, consonance, rhyme elements and assonance. 


\section{Meter}

It is written in iambic pentameter. The choice of iambic pentameter is integral to the form of a sonnet, but it's worth remembering that iambic pentameter is often the form of serious poetry. Iambic pentameter is a rhyme scheme in which each line consists of 10 syllables these syllables are further divided into 5 pairs called iambic feet. However, in line two the first foot isn't iambic. It goes TUM-Ti which just alters the rhythm enough to make us sit up and take notice. This type of foot is called a TROCHEE. The stress falls on the first syllable of 'COral' and this signals a shift as the narrator begins to consider other things that his lover is not like. An iamb is a metrical unit in which one unstressed syllable is followed by a stressed syllable. This establishes a rhythm in the poem. In this sonnet, there is no breaking of the rhythm, or the rhyme, but the couplet at the end stands out. The couplet there contradicts the entire poem where Shakespeare is essentially bashing his mistress, but then says that his:

love as rare / as any she belied with false compare."

When explicating other poems, it is key to note whether the meter, rhythm, rhyme or format change at all during it. If there is a notable change, odds are there is something important there to read into. Reading into a fact, such as "My mistress' eyes are nothing like the sun; / Coral is far more red than her lips' red" is Shakespeare making fun of his mistress, only to retort with how much he loves her in lines 13 and 14. Here is the sonnet's meter:

my MIStress' EYES are NOthing LIKE the SUN;

COral is Far more RED than HER lips' RED;

IF snow BE white, WHY then HER breasts ARE dun;

IF hairs BE wires, BLACK wires GROW on HER head.

I HAVE seen ROSEs Damask'D, red AND white,

But NO such ROSEs SEE IN her CHEEKS;

AND in SOME perFUMES is THERE more DElight

Than IN the BREATH that FROM my MIStress reeks.

I LOVE to HEAR her SPEAK, yet WELL I KNOW

THAT muSIC hath A far MORE pleaSING sound;

I grant I neVER saw A goddESS go;

My MIStress, WHEN she WALKS, treads ON the GROUND.

And YET, by HEAven, i THINK my LOVE as RARE

As ANy she BElieD with FALSE compARE.

\section{The Rhyme Scheme}

The sonnet follows the Shakespearean sonnet pattern in relation to the rhyme scheme as follows: a b a b c d c d e f e f $\mathrm{g} g$. It is written as a whole; it contains three quatrains and a couplet as follows:

\begin{tabular}{|c|c|c|c|}
\hline The First quatrain & $\begin{array}{l}\text { Rhyme } \\
\text { scheme }\end{array}$ & The Second quatrain & $\begin{array}{l}\text { Rhyme } \\
\text { scheme }\end{array}$ \\
\hline $\begin{array}{l}\text { My mistress' eyes are nothing like the } \\
\text { sun; } \\
\text { Coral is far more red than her lips' red; } \\
\text { If snow be white, why then her breasts } \\
\text { are dun; } \\
\text { If hairs be wires, black wires grow on } \\
\text { her head. }\end{array}$ & $\begin{array}{l}\text { A } \\
\text { B } \\
\text { A } \\
\text { B }\end{array}$ & $\begin{array}{l}\text { I have seen roses damask'd, red and } \\
\text { white, } \\
\text { But no such roses see I in her cheeks; } \\
\text { And in some perfumes is there more } \\
\text { delight } \\
\text { Than in the breath that from my } \\
\text { mistress reeks. }\end{array}$ & $\begin{array}{l}\text { C } \\
\mathrm{D} \\
\mathrm{C} \\
\mathrm{D}\end{array}$ \\
\hline The Third quatrain & $\begin{array}{l}\text { Rhyme } \\
\text { scheme }\end{array}$ & The couplet & $\begin{array}{l}\text { Rhyme } \\
\text { scheme }\end{array}$ \\
\hline $\begin{array}{l}\text { I love to hear her speak, yet well I } \\
\text { know } \\
\text { That music hath a far more pleasing } \\
\text { sound; } \\
\text { I grant I never saw a goddess go; } \\
\text { My mistress, when she walks, treads on } \\
\text { the ground: }\end{array}$ & $\begin{array}{l}\mathrm{E} \\
\mathrm{F} \\
\mathrm{E} \\
\mathrm{F}\end{array}$ & $\begin{array}{l}\text { And yet, by heaven, I think my love } \\
\text { as rare } \\
\text { As any she belied with false } \\
\text { compare. }\end{array}$ & $\begin{array}{l}\mathrm{G} \\
\mathrm{G}\end{array}$ \\
\hline
\end{tabular}


The rhyme scheme is MASCULINE, which means the rhymes land on the stressed second beat of the IAMB. If we crunch the poem to focus only on the rhyming words we get:

- Sun - Red - Dun - Head

- White - Cheeks - Delight - Reeks

- Know - Sound - Go - Ground

- Rare - Compare

The fully masculine rhyme scheme is wholly appropriate because this poem is written from a masculine perspective. It offers a male gaze (a point of view that is particularly male and which treats women as objects) and so feminine rhymes (when the rhyme falls on an unstressed beat as in Sonnet 116) would be less appropriate.

\section{Internal rhyme}

My mistress' eyes are nothing like the sun;

Coral is far more red than her lips' red;

I grant I never saw a goddess go;

\section{Sound Devices:}

\section{Alliteration}

Alliteration is the repetition of consonant sounds at the beginning of at least two words in the line of poetry. contains simple words, as well as alliteration to suggest both the simplicity and beauty of the theme and also to reinforce the meaning that the poet desires to convey.

\begin{tabular}{|c|c|c|}
\hline Line & The verse & Alliteration \\
\hline 1 & My mistress' eyes are nothing like the sun; & My, mistress' \\
\hline 3 & If snow be white, why then her breasts are dun; & Be, breasts, white, why \\
\hline 4 & If hairs be wires, black wires grow on her head. & 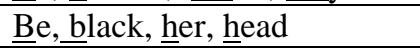 \\
\hline 5 & I have seen roses damask'd, red and white, & Roses, red \\
\hline 6 & But no such roses see I in her cheeks; & Such, see \\
\hline 8 & Than in the breath that from my mistress reeks. & Than, the, that, my, mistress \\
\hline 9 & I love to hear her speak, yet well I know & Hear, her \\
\hline 11 & I grant I never saw a goddess go; & Grant, goddess, go \\
\hline 12 & $\begin{array}{l}\text { My mistress, when she walks, treads on the } \\
\text { ground: }\end{array}$ & 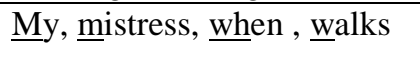 \\
\hline
\end{tabular}

\section{Assonance}

The relatively close juxtaposition of the same or similar vowel sounds, but with different end consonants in a line.

\begin{tabular}{|c|c|c|}
\hline Line & The verse & Assonance \\
\hline 1 & My mistress' eyes are nothing like the sun; & Mistress, nothing, eyes, like, nothing, sun \\
\hline $\begin{array}{l}2 \\
3\end{array}$ & $\begin{array}{l}\text { Coral is far more red than her lips' } \underline{\text { red; }} \\
\text { If snow be white, why then her breasts are dun; }\end{array}$ & $\begin{array}{l}\text { Is, lips, far, than, her, red } \\
\text { Then, her }\end{array}$ \\
\hline 4 & $\begin{array}{l}\text { If hairs be wires, black wires grow on her } \\
\text { head. }\end{array}$ & Hairs, her \\
\hline $\begin{array}{l}5 \\
6\end{array}$ & 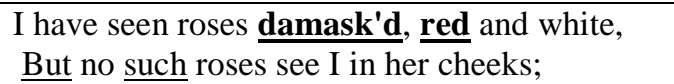 & $\frac{\text { damask'd, }}{\text { But, such }}, \underline{\text { red }}$ \\
\hline 8 & $\begin{array}{l}\text { Than in the breath that from my mistress } \\
\text { reeks. }\end{array}$ & Breath, reeks \\
\hline 9 & I love to hear her speak, yet well I know & Hear, speak \\
\hline 10 & That music hath a far more pleasing sound; & That, hath, far \\
\hline 13 & And yet, by heaven, I think my love as rare & Yet, heaven \\
\hline
\end{tabular}

\section{Consonance:}

The repetition of the same end consonants of words within or at the end of a line ,or the words.

\begin{tabular}{|c|c|c|}
\hline Line & The verse & Consonance \\
\hline 1 & My mistress' eyes are nothing like the sun; & mistress', eyes \\
\hline 2 & Coral is far more red than her lips' red; & Coral, far, more, red, her \\
\hline 3 & If snow be white, why then her breasts are dun; & $\underline{\text { Snow, breasts }}$, her, are \\
\hline
\end{tabular}


A Stylistic Analysis of Shakespeare's Sonnet 130

\begin{tabular}{|c|c|c|}
\hline 4 & If hairs be wires, black wires grow on her head. & Hairs, wires, wires, grow, her \\
\hline 5 & I have seen roses damask'd, red and white, & Damask'吕, red, and, seen, roseses \\
\hline 6 & But no such roses see I in her cheeks; & 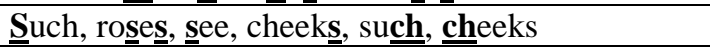 \\
\hline 7 & And in some perfumes is there more delight & Some, perfumes, more \\
\hline 8 & Than in the breath that from my mistress reeks. & 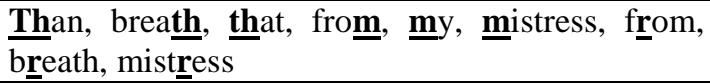 \\
\hline 9 & I love to hear her speak, yet well I know & Hear, her, love, well \\
\hline 10 & That music hath a far more pleasing sound; & That, hath, far, more, music, pleasing \\
\hline 11 & I grant I never saw a goddess go; & goddess \\
\hline 12 & $\begin{array}{l}\text { My mistress, when she walks, treads on the } \\
\text { ground: }\end{array}$ & Mistress, walks, treads, mistress, ground \\
\hline 13 & And yet, by heaven, I think my love as rare & Heaven, think \\
\hline 14 & As any she belied with false compare. & \\
\hline
\end{tabular}

Also the following words that end each line are considered as exemplifying consonance:

Sun, dun (line 1.3), red, head (line 2,4), White, delight (line 5, 7), Cheeks, reeks $(6,8)$ Sound, ground(10, 12),

Rare, compare $(13,14)$

Cacophony: It is the use of a combination of words with loud, harsh sounds - in reality as well as literature. In literary studies, this combination of words with rough or unharmonious sounds are used for a noisy or jarring poetic effect. The following line is an example:

If hairs be wires, black wires grow on her head. (4)

Euphony: It refers to the quality of being pleasant to listen to. Euphony generally comes about through a harmonious combination of sounds and words. An author can create euphony in many different ways, such as using pleasant vowel and consonants, or by employing other literary devices, such as rhythm, rhyme, consonance, and assonance to create an overall harmonious sound to a work of literature. The following line is an example:

As any she belied with false compare. (14)

\section{Repetition:}

It is a literary device that repeats the same words or phrases a few times to make an idea clearer. As a rhetorical device, it could be a word, a phrase or a full sentence or a poetical line repeated to emphasize its significance in the entire text.

- The repetition of the word 'red' in line 2 because it is the color associated with love:

Coral is far more red than her lips' $\underline{\text { red; }}$

It is used to highlight the futility of comparing things which turn out to be fundamentally different; 'red' is applied to coral, lips and roses. 'Roses' is used both literally and figuratively (the supposed 'roses' in a woman's cheeks).

- The repetition of the word 'wires' in line 4:

If hairs be wires, black wires grow on her head.

'Black' is applied to 'wires' and hair. The repetition also, perhaps, conveys a tone of disbelief at how such absurd exaggeration could ever be sincere.

- The repetition of the pronoun I in line 9 and 11:

$\underline{I}$ love to hear her speak, yet well $\underline{\mathbf{I}}$ know

$\underline{I}$ grant $\underline{I}$ never saw a goddess go;

- The repetition of far more in line 2 and 11

Coral is far more red than her lips' red;

That music hath a far more pleasing sound;

- The repetition of the possessive pronoun 'my' four times in the sonnet emphasizes the speaker's ownership of the woman.

My mistress' eyes are nothing like the sun; line (1)

Than in the breath that from my mistress reeks. (8)

My mistress, when she walks, treads on the ground. (12)

And yet, by heaven, I think my love as rare. (13) 


\section{Consonant clusters:}

Consonant cluster refers to a sequence of two or more consonant. Consonant clusters may occur at the beginning of a word (initial cluster), within a word (medial cluster) or at the end of a word (final cluster). These three types of consonant clusters are frequently used in Shakespeare's poem:

\begin{tabular}{|c|c|c|}
\hline Initial consonant cluster & Medial consonant cluster & Final consonant cluster \\
\hline Snow & Mistress & Mistress \\
\hline$\overline{\text { Breasts }}$ & Damask'd & Lip's \\
\hline Grow & Perfumes & Breasts \\
\hline Breath & Goddess & Hairs \\
\hline$\overline{\text { From }}$ & Mistress & Cheeks \\
\hline Speak & Compare & Reeks \\
\hline Pleasing & false & Sound \\
\hline$\overline{\text { Grant }}$ & & Goddess \\
\hline Treads & & Walks \\
\hline$\overline{\text { ground }}$ & & Treads \\
\hline & & Ground \\
\hline & & think \\
\hline
\end{tabular}

\section{Morphological level:}

This level studies how the words are formed, where they originate from, what their grammatical forms are, what the function of prefixes and suffixes in the formation of words are, how system of gender, number, plural etc. morphological devices include affixes and coinage.

Affixes

An affix is added to the root of a word to change its meaning. An affix added to the front of a word is known as a prefix. One added to the back is known as a suffix. Sometimes, prefixes are hyphenated.

$\begin{array}{ll}\text { Suffixes } & \\ \text { Eyes } & \text { eye }+\mathrm{s} \\ \text { Lip's } & \text { lip +'s } \\ \text { Breasts } & \text { breast }+\mathrm{s} \\ \text { Hairs } & \text { hair }+\mathrm{s} \\ \text { Wires } & \text { wire }+\mathrm{s} \\ \text { Roses } & \text { rose }+\mathrm{s} \\ \text { Damask'd } & \text { damask + ed } \\ \text { Cheeks } & \text { cheek }+\mathrm{s} \\ \text { Perfumes } & \text { perfume }+\mathrm{s} \\ \text { Reeks } & \text { reek }+\mathrm{s} \\ \text { Pleasing please }+ \text { ing } \\ \text { Goddess god }+ \text { ess } \\ \text { Walks } & \text { walk }+\mathrm{s} \\ \text { Treads } & \text { tread }+\mathrm{s} \\ \text { Belied } & \text { belie }+\mathrm{d}\end{array}$

\section{Word formational process}

\begin{tabular}{|l|l|l|}
\hline $\begin{array}{l}\text { Word class to which } \\
\text { inflection applies }\end{array}$ & Inflectional category & Affix used \\
\hline Noun & Numbers & S as in reeks, roses, cheeks \\
\hline verb & $\begin{array}{l}\text { First person } \\
\text { Third person }\end{array}$ & $\begin{array}{l}\text { Have seen, see, love, hear, know, grant, saw, } \\
\text { go, think } \\
\text { grow, be, Are, is, reeks, hath, walks, treads, } \\
\text { belied } \\
\text { The tense is present simple and the poet only } \\
\text { used the past simple tense twice in the sonnet }\end{array}$ \\
\hline
\end{tabular}

The poem is written from a first-person viewpoint. This has two major effects. Firstly, it makes the argument of the poem seem universal, not specific to one person. Secondly, it makes it seem more emotional and sincere - if he were speaking about it in third person, he would not be talking about his own experience and the people and events would seem distant. By the constantly referring to the first person "I..." and "My..." it makes the author seem as though he is hypnotized by love - in a trance full of repetition. 
The first word is a $1^{\text {st }}$ person possessive pronoun- a possessive pronoun shows us that the woman belongs to the speaker.

Word derivational process:

Adjective: ing is added to please in order have pleasing

Compounding: Nothing

Parts of speech:

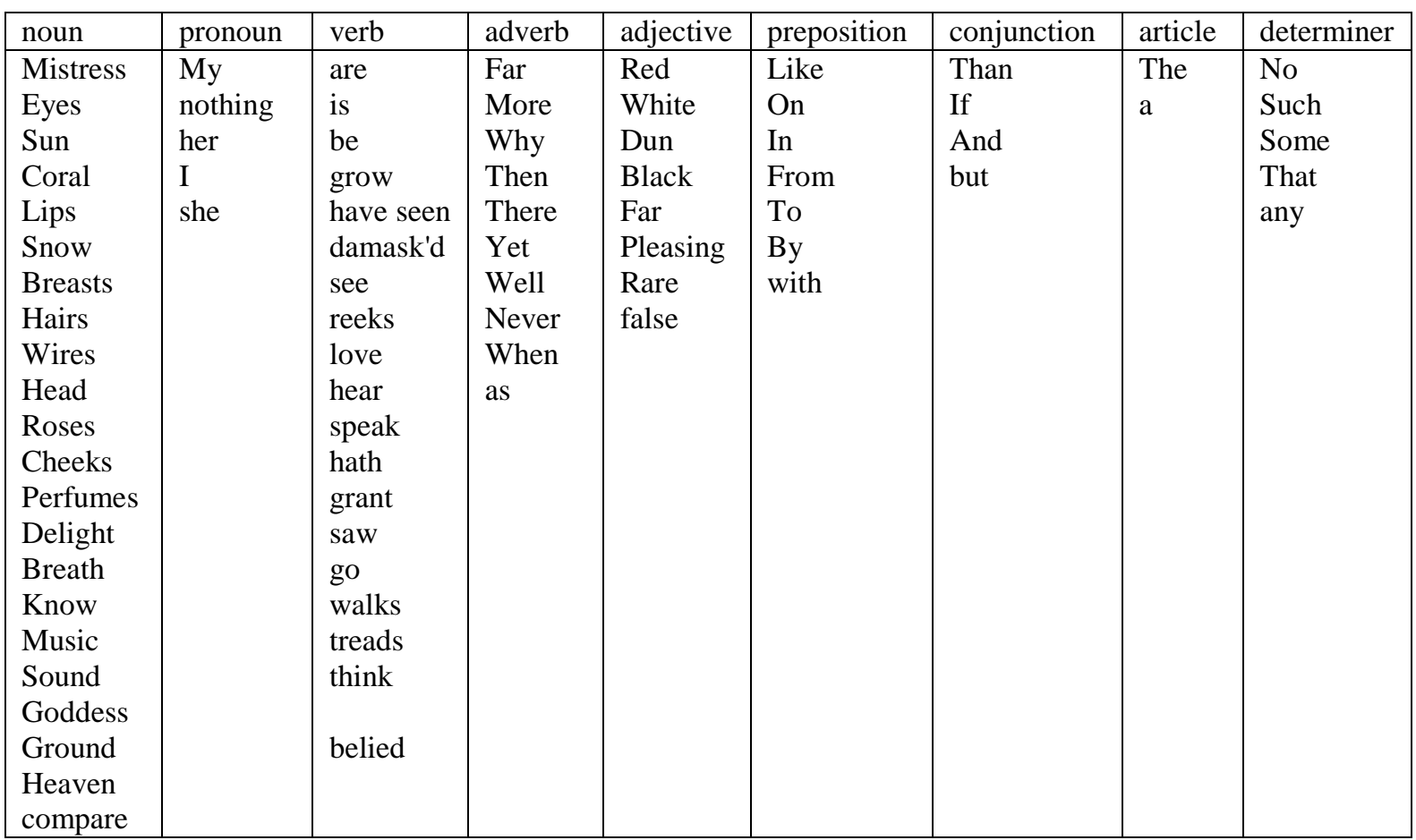

\section{Schemes and troops in the sonnet:}

Schemes and troupes are figure of speech used to create a particular style of writing.

Scheme: Schemes are figures of speech that deal with letters, word order, syntax and sounds rather than meaning of the word.

Tropes: A Trope is a figure of speech that has a different meaning from its literal meaning.

\section{Schemes:}

Anaphora:

It is a scheme. It means the repetition of the same word or group of words at the beginning of successive clauses or sentences.

My mistress' eyes are nothing like the sun; (1)

$\underline{\text { My mistress, }}$ when she walks, treads on the ground: (12)

If snow be white, why then her breasts are dun; (3)

If hairs be wires, black wires grow on her head. (4)

I have seen roses damask'd, red and white, (5)

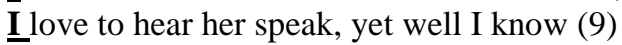

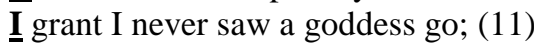

And in some perfumes is there more delight (7)

And yet, by heaven, I think my love as rare (13)

Line 7 begins with the fore grounded conjunction 'and' so we anticipate more comparisons.

Antithesis: 
Antithesis is a scheme that makes use of contrasting words, phrases, sentences, or ideas for emphasis. The most notable poetic device is antithesis, the use of opposites, as the poet breaks his mistress into body parts that are negatives of praise. Shakespeare's Sonnet 130 begins with a quatrain that is filled with antithesis and makes good use of caesuras. In sonnet 130 Shakespeare used antithesis as a useful poetic device to convey his ideas where he breaks his mistress into body parts that are negatives of praise: "nothing like the sun," "coral is much more red," "her breasts are dun" and "black wires spring from her head." The device fragments the mistress. Shakespeare may not have been trying for all that, but his use of antithesis also gives her reeking breath, unmusical sound and an earthly tread. The overall effect of these devices gravitates toward the final lines, which express the sentiments you might expect from an antithetical, allusive parody of sentimental poetry. The poet loves the mistress, warts and all; he has no illusions of false poetic beauty. Affirmation wins over alienation. Here are some examples:

My mistress' eyes are nothing like the sun;

The poet used the word 'mistress' as an indication to his beloved woman. Yet in the same line he used in the word a negative simile 'nothing like' to say she does not have sun-like eyes.

Coral is far more red than her lips' red;

In this line he says that the actual red coral is literally more red than her lips. Using far more here intensifying the fact that her lips are definitely not a deep red color.

If snow be white, why then her breasts are dun;

The writer is saying that the woman does not have white skin or golden hair which were both things that were beautiful features for women.

If hairs be wires, black wires grow on her head.

Shakespeare's use of antithesis also gives her reeking breath, unmusical sound and an earthly tread.

\section{Tropes:}

In this sonnet Shakespeare expresses his dislike of the way that most poets follow when they write their sonnets which are about the beauty of the lover. Shakespeare tries in this sonnet to mock the typical Petrarchan or Italian sonnet and he parodies it by presenting a speaker who seems to take them at face value, and somewhat bemusedly, decides to tell the truth. During that time sonnets tended to make highly idealizing comparisons between nature and the poets' lover that were completely ridiculous and fake from the point of Shakespeare's view. Shakespeare's sonnets subvert and reverse the conventions of the Petrarchan love sequence. The entire poem parodies Petrarchan sonnets. In this sonnet, Shakespeare's parody of romantic women renders up a real woman, not a goddess, whom Shakespeare considers "as rare as any she belied with false compare." He parodies false flattery with truth. In order to convey his ideas he used several literary tropes as follow.

\section{Hyperbole:}

Hyperbole is a trope composed of exaggerated words or ideals used for emphasis and not to be taken literally. Shakespeare used hyperbole in his sonnet in a different way because at that time most poets wrote sonnet to decorate the lover with hyperbole praise. Shakespeare decided to take the similes and metaphors in this sonnet in the other direction where he exaggerated his love's weakness rather his strength. Shakespeare decided in this sonnet to exaggerate how unattractive his mistress is. Sonnet 130 suggests that his mistress' hair is made of black wire, her breath reeks, her breasts are grayish brown and her voice is grating.

\section{Imagery: \\ Simile:}

William Shakespeare's sonnets are full of beautiful and striking similes. In Sonnet 130, he used strange indirect similes as follows:

My mistress' eyes are nothing like the sun. (1)

The poet uses a direct comparison between his mistress' eyes and the sun. He compared a sun with his mistress' dark eyes in order to portray the dull, boring and lifeless quality of her eyes in order to emphasize the dullness and lifelessness.

Coral is far more red than her lips red (2)

The poet here compares his mistress' lips to red coral where he portrays an amazing image that the reader imagines bright red coral in a sea full of grey water; it is drawing our eyes towards the pure and nice color and by having the grey water background the poet emphasizes the lifeless color of his mistress' lips. 
'If snow be white, why then her breasts are dun' (3)

In this line, Shakespeare is so satirical and he avoids a direct simile, instead just he gives us the strong image of sparkling white snow, and lays it next to the equally strong image of dun breasts. In this line William Shakespeare plays uses colors to convey his idea; he uses white as a symbol of purity, cleanliness, virginity, and all that, next to that squeaky clean image, the mistress's breasts look dirty and polluted.

'I have seen roses damask'd, red and white, but no such roses see I in her cheeks' (5)

Here the poet compares cheeks with roses but he cannot see roses in his mistress' cheeks. This line highlights the dull and boring qualities of the his beloved lady.

'And in some perfumes is there more delight than in the breath that from my mistress reeks' (6)

Also here Shakespeare avoids direct simile. His mistress' breath is compared to perfumes but unfortunately there is more delight in perfumes than in his mistress breath.

'I love to hear her speak, yet well I know that music hath a far more pleasing sound' (7)

Shakespeare avoids direct simile here. He says that music has a far more pleasing sound than his mistress' voice. He does not say that his mistress' voice was horrible, only that music sounds far more pleasing.

I grant I never saw a goddess go;

my mistress when she walks treads on the ground:

in the previous lines we have another simile where the poet says that his mistress' stride is like a goddess.

\section{Metaphors}

The next common device used in the poem is metaphor. While in the traditional Petrarchan or Italian sonnet, metaphors are used to amplify the beauties of the beloved, Sonnet 130 is an "anti-Petrarchan" sonnet, and the metaphors often act to parody the exaggerations of the Italian tradition, and create a sense of realism. Such metaphors include the description of hair as "black wires" and cheeks as "dun" when compared to roses.

If hairs be wires, black wires grow on her head. (line 4)

Metaphor: the word wires is not literal it refers to golden wire, as women who had beautiful hair were told they had hair like golden wire. This line contains a metaphor where the poet is making analogy between wires and his mistress' hair.

\section{Allusion}

Allusion, the reference to outside works or events, grounds the poem in conflict, so that we can assume the mistress and poet battle when they're not lusting for each other. The poet uses allusion in the following lines:

If hairs be wires, black wires grow on her head.

I have seen roses damask'd, red and white, (4-5)

Here we have an allusion possibly to the rose known as the York and Lancaster variety, which the House of Tudor adopted as its symbol after the War of the Roses. The York and Lancaster rose is red and white streaked, symbolic of the union of the Red Rose of Lancaster and the White Rose of York.

He also alludes to the then-overused metaphor of beloved women as angels who tread clouds, stating that in reality in the following line:

My mistress, when she walks, treads on the ground: (13)

Also there is some allusion in Shakespeare's Sonnet 130 which is considered as religious in line 14 when he used the word 'heaven':

And yet, by heaven, I think my love as rare (14)

\section{Connotation}

The connotation of a word refers to the emotional or cultural association with that word rather than its dictionary definition. Connotation plays a role in almost every type of communication, as it adds nuance and more subtle meaning. Authors use connotation to allow the readers to infer more meaning than there is explicitly written on the page, making the readers more active parts of the interpretive process.

My mistress' eyes are nothing like the sun;

Coral is far more red than her lips' red; 
If snow be white, why then her breasts are dun;

If hairs be wires, black wires grow on her head.

In this famous sonnet, Shakespeare compares his lover unfavorably to many wonderful things. Shakespeare uses the sun, the coral, and the snow to connote beauty, love, and purity. By saying that his lover is not like any of these things, she carries none of their connotations. Therefore, she is not beautiful and certainly not pure or innocent.

\section{Synecdoche:}

Synecdoche is a figure of speech in which a part of something is used to represent the whole or the whole of something is used to represent part of it. It is considered to be a special kind of metonymy. In sonnet 130 the synecdoche is found in lines 5 ad 6 :

I have see roses damask'd, red and white,

But no such roses see I in her cheeks.

In the previous lines, Shakespeare views his mistress as a whole like a rose, but not in her cheeks does he see the rose.

\section{CONCLUSION}

This study shows the stylistic analysis of sonnet 130 at different levels of stylistics. Sonnet 130 is a love poem which shows the love of poet towards his beloved but described in a different way. The poet says that his lady is not so beautiful but for him she is the most beautiful lady ever born on earth. In this work of analysis different aspects of sonnet 130 are elaborated. The poem is analyzed on phonological, graphological, lexical and grammatical level. Schemes and troops which are used in this sonnet are also mentioned in this study.

\section{REFERENCES}

[1]. Carter, R. (1989). What is stylistics and why do we teach it in different ways? In M.Short, (Ed), Reading, Analysing and Teaching Literature. London: Longman.

[2]. Haynes, J. (1989), Introducing Stylistics, London \& New York: Unwin Hyman Ltd.

[3]. Larsen, Kenneth J. Essays on Shakespeare's Sonnets. Retrieved from http://www.williamshakespearesonnets.com/wp-content/uploads/KJLessays.pdf on January 5th , 2017.

[4]. Lawal, R. A. (1997), Pragmatics in Stylistics: A speech -Act Analysis of Soyinka's 5. Telephone Conversation, R.A Lawal (ed.) Stylistics in theory and practice, Ilorin: Paragon books.

[5]. Leech, Geoffrey and Mick Short (1981). Style in Fiction, London: Longman

[6]. Widdowson, H.G. (1975), Stylistics and the teaching of literature, London: Longman Group Ltd.

[7]. Turner, G.W. (1975) .Stylistics . Benguin Books. London. [19].

[8]. Verdonk, P., Stylistics, Oxford: Oxford University Press, 2002.

[9]. http://libvm3.library.vanderbilt.edu/bitstream/handle/1803/3138/MarcusRobertHerrick1993.pdf?sequence $=1$ 